\title{
Context - Based Teaching Strategy (CBTS) for Effective Learning of Simple Alternating Current (A.C.) Circuits in Senior Secondary School Physics
}

\author{
Eyenaka, F.D. \\ Ekanem, C.H. \\ Uwak, S.O. \\ Department of Physics, \\ Akwa Ibom State College of Education, \\ Afaha Nsit, Akwa Ibom State, Nigeria
}

\section{Doi:10.5901/jesr.2013.v3n8p55}

\begin{abstract}
The paper investigates the context-based strategy of teaching Senior Secondary School Alternating Currents (A.C) Circuits in Physics. A quasi-experimental design was adopted for the study of 450 SSS // Physics students (250 males and 190 females) drawn from 10 out of 85 secondary schools in Ikot Ekpene Education Zone. Three null hypotheses were formulated and tested at 0.05 levels of significance. Simple Alternating Current Circuits in Physics Achievement Tests (SACPATS) was employed in the data collection. The instrument was validated (reliability coefficient=0.56) and administered both as pre- and post- tests. The data were statistically analyzed. Results were that context-based teaching strategy was significantly better than the expository method in enhancing students' transfer of learning in simple alternating current (A.C) circuits in Physics with respect to gender and school location. Recommendation made, among others, was that context-based teaching strategy be adopted in teaching and learning of Physics concepts in Nigerian schools.
\end{abstract}

Keywords: Context-based teaching strategy (CBTS), Academic achievement, Simple Alternating Current $(A C)$ Circuits, Transfer of learning, Physics concepts.

\section{Introduction}

Physics is a branch of Physical Science that concerns mainly with matter in relation to energy (Olumuyiwa and Okunola, 1992). Physics, as a fundamental science provides a basis for creative work in various fields of modern science and technology and offers excellent background for various professional studies and competence in effectively relating what is learnt in school to real life situations outside of school (Ekanem, 2000b). It has been acknowledged as a pre-requisite for the study of several courses in the universities. For example, Engineering, Medicine and other applied science courses need physics. Physics Education is generally aimed at equipping the individual learner with such knowledge, skills and attitudes that will enable him live a meaningful and fulfilled life and contribute positively to the development of the society from which he can derive maximum social, economic and cultural benefits (NERDC, 2004). Yet, in spite of the great importance of Physics in our national development and the efforts being made by the government, researchers, Science Teacher's Association of Nigeria (STAN) and other agencies, students' achievements in Physics have been poor and unsatisfactory. Enabling the learner acquire functional skills in Physics calls for well-planned academic programmes being put in place to address some 
issues that adversely militate against effective teaching and learning of Physics-based concepts and principles in school and to stem the low ebb with which the learners of this academic discipline effectively transfer what they learn while in school to real life situations outside of school (Ekanem, $2000 \mathrm{~b})$. And, in view of the obvious importance of Physics in the scientific and technological advancement of any nation, and its usefulness in most fields of human endeavour, there is need to develop effective strategies in the teaching of this course in our schools, colleges and universities.

However, various studies have shown that students find it difficult to learn certain Physics concepts (Onwioduokit, 1996; Ekanem, 1998; Ogunleye, 2000; Okonkwo, 2002; Nnadi, 2002; Azim, 2002; Ajeyalemi, 2003; Ezeudu, 2003). In a study, "Issues and Problems of Teaching and Learning Physics in Nigeria", Ekanem (1998) cites some Physics concepts that senior secondary school students in Nigeria find difficult to learn and discusses some causes of poor performance of the learners of the subject in external examinations. For example, poor teaching methods have been predominantly in use for a long time in the teaching of Physics concepts (Okonkwo, 2002; Ajeyalemi, 2003). These include the traditionally based lecture and expository methods. These methods are said to be didactic, stereotyped, dull, and therefore, not result oriented (Azim, 2002; Ezeudu, 2003). Some methods such as demonstration, guided inquiry and discovery methods could be result-oriented but have been reported to have made students fail to see the inter-dependent relationship that exist between academic contents of Physics courses offered while in school and their real life applications (Ekanem, 2000b). The tide now seems to be more critical in the assimilation/comprehension and subsequent transfer of the learning of Alternating Current (A.C) circuit concepts in terms of appreciating the various A.C. circuits concepts and the conducting paths along which alternating electrical current (which periodically reverses its direction as it flows through the conductor) flows (Mkpanang, 2010). Onwioduokit (1996) and Mkpanang (2010) have independently shown that the Peak and the Root Mean Squared (RMS) values of A.C. Resistance, Capacitance, Inductance and Power in A.C circuits as well as Resonance in Resistance-InductanceCapacitance (RLC) series circuits are all aspects of simple A.C circuits which pose some levels of difficulties to comprehend by Senior Secondary School Physics students. Furthermore, NERDC (2004) confirms that many teachers of Alternating Current (A.C) circuits in Physics believe that their students find this sub-discipline of Physics difficult to learn. One of the reasons adduced for students' poor performance in certain areas of the SSCE simple A.C circuits in Physics is its method of teaching which most of the students find uninteresting (Mkpanang, 2010). Based on the shortcomings of the already existing methods of teaching certain "difficult" physics-based concepts, Okonkwo (2002), for example, proposed the need for a search for better instructional methods that would enhance the attainment of better learning outcomes. Notable among such innovative approaches is the Context-Based Teaching Strategy (CBTS) (Bennett, 2003).

Bennett (2003) defines context-based teaching strategy as an approach adopted in science teaching where contexts and application of science are used as the starting point for the development of scientific ideas, concepts and principles. This contrasts with the more traditional approaches that present scientific ideas, concepts and principles first before considering the applications.

Context-based teaching strategy (CBTS) thus involves the connection of the teaching of a particular concept within its context as a science-based discipline or concept as well as its connection to students' lives in the real world.

However, some evidence abound in the literature (Ekanem, 1998; 2000b; Ogunleye, 2000) that has shown that some factors, either singly or in combination with instructional methods used in disseminating Physics-based lessons, influence students' achievement in the subject. Specifically, some studies have been carried out to find out the influence of gender (Azim, 2002; Anidu, 2007) and location (Azim, 2002) on students' achievement in science generally and on the students' achievements in Physics in particular. Unfortunately, the findings seem to be contradictory and inconsistent. For example, Azim (2002) finds that there is no significant difference in the achievement of male and female students in Physics while Ogunleye (2000) observes a significant 
difference in achievement with respect to gender. Also, influence of school location on students' achievement in science is equally contradictory (Daluba, 2011); Obinne, 2007). According to Daluba (2011), urban students out-performed their rural counterparts in science achievement test. This finding is contrary to that of Obinne (2007) that students in rural schools perform significantly better than their counterparts in urban schools. These studies may have failed to consider other variables such as the influence the teaching method used may have on the subjects before administering the respective instruments. Moreover, the combined effect of each of the factors of gender and school location in Physics achievement hitherto shown to be contradictory with the CBTS has not been explored. In consideration, therefore, of the inconclusiveness of these previous studies with respect to gender and location in science achievement, there is need to carry out the present study to determine how the CBTS would affect students' academic achievement in simple A.C circuits in Physics with respect to gender and location.

\section{Statement of the Problem and Purpose of Study}

Over the years, the achievements of students in Physics in Nigerian secondary schools have been very poor. This is because these students fail to see the inter-dependent relationship that exists between the academic contents of Physics subjects offered in school and their applicability in real life. As a result there is low transfer of what is learnt in the school to the real-world. This is the gap that this study is construed to fill.

The purpose of this study is, therefore, to determine the effects of context-based teaching strategy on senior secondary schools students' achievement in simple A.C. circuits in Physics. The study was specifically designed to:

i. Determine the difference in students' achievements when taught simple A.C. circuits in Physics with context-based teaching strategy (CBTS) and when expository method of teaching (EMOT) is used;

ii. Determine difference in achievement of male and female students taught simple A.C. circuits in Physics with CBTS;

iii. Determine difference in achievement of contemporary students of urban and rural schools taught simple A.C. circuits in Physics with CBTS.

\section{Research Hypotheses}

In this study, three null hypotheses $\left(\mathrm{Ho}_{1}, \mathrm{Ho}_{2}\right.$ and $\left.\mathrm{HO}_{3}\right)$ were formulated and tested for significance at 0.05 error margin. They are:

- Hol: There is no significant difference in the achievements of Senior Secondary School students taught simple A.C. circuits Physics concept using context-based teaching strategy and those taught with expository method.

- Ho2: There is no significant difference between the academic achievements of the Senior Secondary School male students and their female counterparts taught simple A.C. circuits Physics concept using context-based teaching strategy.

- Ho3: There is no significant difference between the academic achievements of the contemporary rural and urban Senior Secondary School students taught simple A.C. circuits Physics concept using context-based teaching strategy.

\section{Methodology}

A quasi-experimental (the non-equivalent pre-test- post-test control group) design was adopted for the study. All the senior secondary school II (SSS 2) Physics students in the Ikot Ekpene education zone of Akwa Ibom State, Nigeria formed the population of the study. Stratified random sampling technique across gender and school location was used to select ten (10) out of eighty-five (85) 
schools in this Education Zone. Simple Alternating Current (AC) Circuits in Physics Achievement Tests (SACPATs) were employed in the data collection. The instrument was face- and contentvalidated by three experts in Science Education Department of the University of Uyo, Uyo, Nigeria. The comments and suggestions of the experts were incorporated in building up the final draft of the instrument. The instrument was trial-tested on 40 SSS II students drawn from secondary schools that were not involved in the main study. The result was used to determine the reliability of the instrument using Kuder-Richardson formula 20 and the consistency index obtained for the SACPATs was 0.56 . The SACPAT instrument was administered as both the pre-test and post-test by the substantive Physics teachers of the sampled schools. The data obtained were analyzed using mean, standard deviation and t-test statistical tools.

\section{Results}

Table 1: t-test analysis of academic achievement of Physics students in SACPATs using Context Based Teaching Strategy (CBTS)

\begin{tabular}{|c|c|c|c|c|c|c|c|c|c|}
\hline Variables & & $\mathrm{N}$ & $\bar{x}$ & S.D & Df & t-cal & t-crit & Decision & \\
\hline Experiment (CBTS) & 300 & 39.3 & 25.8 & & & & & & \\
\hline & & & & & & 448 & 8.05 & 1.96 & * \\
\hline Control (EMOT) & 150 & 10.3 & 7.8 & & & & & & \\
\hline
\end{tabular}

The results as shown in table 1 indicate that the calculated t-value (8.05) exceeds the critical tvalue (1-96) at 0.05 alpha levels of significance. This implies that hypothesis one is rejected in favour of the alternative hypothesis that there is a significant difference in the achievements of Senior Secondary School students taught simple A.C. circuits Physics concept using context-based teaching strategy and those taught with expository method.

This means that there are significant differences in the achievements of students taught simple A.C circuit in Physics using context-based teaching strategy and those taught with expository method of teaching.

Table 2: t-test Analysis of the influence of gender on Physics achievement using CBTS

\begin{tabular}{|c|c|c|c|c|c|c|c|c|}
\hline Gender & $\mathrm{N}$ & $\bar{x}$ & S.D & Df & t-cal & t-crit & Decision & \\
\hline \multirow[t]{2}{*}{ Male } & 260 & 48.3 & 18.2 & & & & & \\
\hline & & & & & 448 & 9.4 & 1.96 & * \\
\hline Female & 190 & 33.4 & 13.6 & & & & & \\
\hline Total & 450 & 40.85 & 15.9 & & & & & \\
\hline
\end{tabular}

The results in table 2 show that the t-calculated (9.4) exceeds the critical t-value (1.96) at 0.05 levels of significance. This implies that hypothesis two is rejected. The conclusion on this result is that gender has significant effect on Physics achievement of Senior Secondary students using CBTS. 
Table 3:t-test analysis of the effect of the school location on Physics achievement using CBTS

\begin{tabular}{lrrrrrrrr}
\hline School Location & $\mathbf{N}$ & $\mathbf{X}$ & S.D & Df & t-cal & t-crit & Decision & \\
\hline Urban & 225 & 14.37 & 5.86 & & & & & \\
& & & & 448 & 0.32 & 1.96 & $* *$ \\
Rural & 225 & 14.54 & 5.27 & & & & & \\
\hline Total & 450 & 14.455 & 5.565 & & & & & \\
$* *=$ Not Significant at P<0.05 & & & & & &
\end{tabular}

From table 3 , the t-calculated $(0.32)$ is less than t-critical value (1.96) at 0.05 alpha levels of significance. This means that hypothesis three is accepted. This implies that the achievements of physics students in rural secondary schools are generally comparable to (that is, neither better nor worse than) that of their contemporaries in urban schools all with respect to the teaching and learning of simple A.C circuits using CBTS.

\section{Discussion}

The tests mean scores of the subjects with respect to the teaching method used as well as the statistical analyses/results of this study show that the method of presenting Physics-based concepts and principles in general and particularly simple alternating current (A.C.) circuits in physics is a significant contributing factor to failure of, or, the low ebb with which the learners of this academic discipline effectively transfer what they learn while in school to real life situations outside of school.

The findings of this study show that context-based teaching strategy is significantly better than expository method of teaching. The results of testing the first hypothesis thus reveal the efficacy of CBTS on academic achievement of secondary school students in Physics (that is, the subjects taught using the experimental method achieved better than their counterparts who were taught using the control method). These results are in line with Ekanem's (2000b) and Azim's (2002) position that some traditionally used method of teaching Physics such as demonstration, guided inquiry, discovery methods could be result-oriented but have made students fail to see the inter-dependent relationship that exist between academic contents of Physics courses offered while in school and their real life applications. This finding further buttresses the earlier position of Bennett (2003) and Ogunleye (2000) that some factors have been shown to either singly or in combination with instructional methods used in disseminating Physics-based lessons influence students' achievements in the subject. Based on these findings, the current researchers posit that students taught using innovative teaching methods such as CBTS perform better than those taught using the expository method respectively in terms of achievement.

The result of testing the second hypothesis shows that secondary school students differ significantly in their academic achievement using gender as a variable of interest. This implies that gender is a significant factor in students' achievements in simple (A.C) circuits in Physics. This finding appears to support the views of Eziobu (2005) and Nnadi (2002).

Similarly, Azim (2002) in his study of the relative effectiveness of guided-inquiry and expository instructional methods on students' achievements in Physics found that there is a significant difference in the transfer of learning between male and female students. In particular, the current study found that the Senior Secondary School male students performed significantly better in the achievement tests than their female counterparts when taught simple A.C. circuits Physics concept using the context-based teaching strategy. However, the findings of the present study differ from the findings of Nnadi (2002) who reported that female students performed better than their male counterparts, in favour of Esiobu (2005) who reported that male students are better than female students all with respect to academic achievement.

The results of the present study further show that location is not a significant factor in 
students' achievements in the learning of simple Alternating Current (A.C) circuit concepts in Physics with respect to the teaching method used on the subjects. This assertion was arrived at by testing the third hypothesis formulated for this study which, in recap, states that there is no significant difference between the academic achievements of the contemporary rural and urban senior secondary school students taught simple A.C. circuits Physics concept using context-based teaching strategy. In other words, students in the urban area are not found to perform better in SACPATs than their contemporaries in the rural schools given the same extraneous conditions.

These results are in agreement with Akpan (2009) who found no significant difference between urban and rural students' acquisition of Physics process skills.

They are, however, in disagreement with Nworgu and Madu (1996) who found significant differences between urban and rural students in their achievement in science teaching and learning.

\section{Recommendations}

Based on the findings of the current study, the following recommendations are made:

- The Government through the Federal and State Ministries of Education should organize and sponsor physics workshops, exhibitions, quizzes, seminars and conferences on a regular basis aimed at upgrading the knowledge status of the teachers.

- Physics teachers should endeavour to use the context-based teaching strategy in teaching simple Alternating Current (A.C) Circuit and some other Physics-based concepts that are tagged "difficult" since this method enhances achievement and has the potentials of developing critical thinking and creative abilities in the students.

- Students should be serious, hardworking, initiative and creative to enable them carryout independent or group work, such as assignments or project given to them by the Physics teachers. These are necessary in CBTS teaching - learning processes.

\section{Conclusions}

Considering the great importance of Physics in our national development, which coincide with one of the objectives of Physics curriculum by the Federal Ministry of Education to show physics and its link with industry, everyday life, benefits and hazards, and efforts being made by government, Science Teachers' Association of Nigeria (STAN) and other agencies in promoting achievement in the subject, it is construed that context-based teaching strategy will help in making the above laudable objective and those efforts feasible. One way of ensuring an improved performance of the learners during the external examination is by making them appreciate the inter-dependent relationship that exists between academic contents of Physics concepts presented in the teachinglearning situations while in school and their real life applications. If we are able to achieve this transfer of what is learnt in school to the real-world then improved achievement in external examination, irrespective of gender or school location, can be achieved.

\section{References}

Ajeyalemi, D. A. (2003). Physics Teaching in an Out-of-Class Learning Environment, In Proceedings, 47th annual Conference of STAN: 294-297.

Akpan, B. O. (2009). Development and validation of an instrument for the assessment of science process skills acquisition in practical physics: PhD thesis of the University of Nigeria, Nsukka.

Anidu, I. C. (2007). A comparative study of co-operative learning and concept-mapping instructional strategy on senior secondary students' achievements, interest and retention in Biology: M.Sc. thesis of the Department of Science and Computer Education, Enugu State University of Science and Technology, Enugu. 
Azim, C.M. (2002). The relative effectiveness of guided-inquiry and expository instructional methods on students' achievement in Physics; South West Women in Colleges of Education Journal 1(1):

Bennett, J. (2003). Context-based approaches to the teaching of science; In: Teaching and Learning of Science: 99-122. London, UK: Continuum.

Daluba, N. E, (2011). Effects of demonstration and problem solving methods of teaching on students' achievement in Agricultural Science: PhD thesis of the University of Nigeria, Nsukka.

Ekanem, C. H. (1998). Issues and Problems of Teaching and Learning of Physics in Nigeria; Nigerian Educational Journal, 2 (1): 95-100; Calabar; Publication of the National Association of Professionals in Education.

Ekanem, C. H. (2000b). Curriculum Issues in Nigeria's Basic Education Scheme; International Journal of Research in Basic and Life-long Education; 1(1\&2): 82-88; Calabar: Publication of the Institute of Education, University of Calabar.

Esiobu, G. O. (2005). Gender Issues in Science and Technology Education for Development; In: Ivowi, U. M. O. (Ed.) Science and Technology Education for Development, Lagos, Adecos Education Science Ltd.

Ezeudu, A. N (2003). Effect of concept maps on students' achievements, interests and retention in selected topics in physics; PhD thesis. University of Calabar, Calabar.

Mkpanang, J. T. (2010). Practical activity as an instructional strategy for teaching simple alternating current (A.C) circuits in physics. Journal of the Science Teachers Association of Nigeria, STAN (Physics Panel), 1(1):

NERDC (2004) National Educational Research and Development Centre: National Policy on Education, Abuja: NERDC Press.

Nnadi, F. O. (2002). Facilitating conceptual change, achievement and retention in physics using analogy and PPEEFA instructional package; M.Sc. thesis. Enugu State University of Science and Technology.

Nworgu, B. C. \& Madu, B. C. (1996). Evaluation of the constructivistic-based instructional model relative to students' conceptual change in Physics; Journal of Technical and Science Education, A publication of the Faculty of Technical and Science Education, River State University of Science and Technology, Port Harcourt, 14(1,2): 25-34.

Obinne, A. (2007). Psychometric properties of senior certificate biology examinations conducted by West African Examinations council and National Examination council: application of item response theory, PhD thesis of the University of Nigeria, Nsukka, Nigeria.

Ogunleye, J. J. (2000). Effects of concept-mapping method of instruction on students' achievement and learning retention in physics; M.Sc. Dissertation of the Department of Science Education, University of Port Harcourt, Nigeria.

Okonkwo, J. G. (2002). Modern trends in Physics teaching at the secondary schools level; In: Ayodele, S.O. (Ed.); Teaching strategies for Nigerian secondary schools; Ibadan, Powerhouse publishers: 230-241.

Olumuyiwa, A.\&Okunola, O. (1992). Comparative Certificate Physics, Ibadan, Ibadan University Press PIc.

Onwioduokit, F. A. (1996). Difficult concepts in physics as experienced by senior secondary students in Akwa Ibom State, Journal of Research Information: 1(1): 19 - 28. 
